\title{
Characterization of Teatina Coast Marine Habitats (Central Adriatic Sea) toward an Integrated Coastal Management
}

\author{
Maria Carla de Francesco ${ }^{1 *}$, Carlo Cerrano ${ }^{2}$, Daniela Pica $^{2}$, Dario D Onofrio ${ }^{2}$ and Angela Stanisci ${ }^{1}$ \\ ${ }^{1}$ University of Molise, Italy
}

${ }^{2}$ Polytechnic University of Marche, Italy

Submission: August 12, 2017; Published: October 13, 2017

*Corresponding author: Maria Carla de Francesco, University of Molise, via Duca degli Abruzzi, 86039 Termoli, Italy, Tel: 00393470781143 ; Email: maria.defrancesco@unimol.it

\begin{abstract}
The Adriatic Sea represents a vulnerable ecosystem and need an Integrated Coastal Management to protect, conserve and manage the coastal and marine areas. This preliminary work proposes a local case study aimed to the characterization of coastal marine habitats along Teatina coast (Abruzzo, central Italy), carrying out 11 transects parallel to the coastline. Moreover, the presence of sea turtles and cetaceans has been estimated by the analysis of specimens stranded and included in the GeoCETUS database of Centro Studi Cetacei onlus. The results show that the study area has a considerable marine biodiversity and a sustainable management is urgent for preserving the habitats and associated species. As first step the Nature 2000 network should be implemented by including the marine areas in front of each terrestrial SCIs and Natural Reserves, to create some marine protected areas along Teatina coast with the aim to match the socio-economic needs of the territory and the conservation of natural habitats. Our results only represent a first step and further socio-economic analysis should be implemented to establish an integrated management plan together with the regional authorities.
\end{abstract}

Keywords: Bionomic characterization; Centro studi Cetacei onlus; Coastal environment monitoring protocol; Coastal habitats; GEOCETUS database; Marine habitats; Nature 2000 network

\section{Introduction}

In the Mediterranean Sea, the Adriatic is the most productive basin hosting endemic species and marine mammals, sea turtles, seabirds, fishes and invertebrates, and also the nursery, spawning, and foraging areas [1]. The overexploitation of resources and the increasing of human activities on the coastal areas from the fifties to the present day [2] have impacted the shallow water benthic communities modifying and impoverishing the marine habitats [3]. Moreover, the erosion processes involve both the sandy beaches and the rocky coasts losing important coastal and marine habitats and species [3]. Furthermore the description and the distribution of Adriatic benthic communities have been studied on a larger and a local scale [4-6] but the information about marine biocoenosis and biodiversity in the Teatina coast (Abruzzo, central Italy) now is poor and not exhaustive to structure management programs. In the central Adriatic Sea, the Teatina coast represents a particularly environment composed by shallow rocky cliffs generating pebble beaches alternated by sandy beaches. Along this coast there are promontories too, such as Punta Ferruccio, Ripari di Giobbe, Punta Acquabella e Punta Aderci [7]. Sandy beaches are characterized by established dunes and incipient dunes especially occur at the southern part of the Teatina coast. The marine substrates are characterized by seagrass habitat (Cymodocetum and Zosteretum), the rockyalgal reef and unvegetated sand habitats; the Posidonia oceanica seagrass beds are present only in the southern Adriatic Sea at depth greater than 20 meters [8].

The aim of our work is to improve the knowledge about marine biodiversity and EU habitats and associated species along Teatina coast (Abruzzo, central Italy) for promoting a sustainable management of such resources, as required by European Commission to implementing the marine Nature 2000 sites (EU-Pilot 83/16/ENVI case) according to the criteria identified by Annexex II and III Habitat Directive 92/43/CEE.

The study of the marine habitats was carried out through the distribution of sampling stations along 11 transects of 500 meters parallel of coastline between the municipalities of 
Ortona and Vasto (central Italy) from -1 to -10 meters in depth at natural rocky shores and associated ichtyofauna. In each station the sampling was carried out through visual census method (specimens/minutes), standardized by Coastal Environment Monitoring Protocol (CEM) with the cooperation of researchers, scuba divers and managers of the coastal/marine preserved areas (https://www.reefcheckmed.org/english/underwatermonitoring-protocol/). For each transect, was recorded the presence/absence, the number and frequency of specimens of guide species for marine environment $[9,10]$. Finally, were identified the marine habitats [11] and the Biotopes CORINE [12] and the EUNIS [13] typologies.

Data of sea turtles and cetaceans stranded along Teatina coast were collected in GIS format in the GeoCETUS website (http://geocetus.spaziogis.it/) by the Centro Studi Cetacei onlus CSC (Cetacean Study Centre-onlus), established by the Museum of Natural History of Milan in October 1985 by several researchers from the Italian Natural History Museum and other Italian scientific institutions and now responsible of the Recovery Center for sea turtles 'Luigi Cagnolaro' on Pescara, central Italy $[14,15]$.

\section{Discussion}

Marine substrates at $-7 /-10$ meters in depth showed well-calibrated fine and silty sand in quiet environments of Mediterranean Sea with association of seahorse grass Cymodocea nodosa (EUNIS 4.5131) referred to sandbanks (EC habitat code 1110 ) in continuous with estuaries (EC habitat code 1130) of the largest rivers along the Teatina coast (Sangro, Sinello) in contact with riparian woods with Salix alba and Populus alba (EC habitat code 92A0) [16,17].

The benthic populations found in sandy substrates are especially endobionts, as bivalves Tellina $s p$, Donax trunculus, Chamalea gallina, Cardium edule, Ensis ensis, Solen vagina, Mactra corallina, and the gasteropods Aporrhais pes-pelecani, and the echinoderms Echinocardium cordatum and Astropecten sp.

Infralittoral rock included habitats of bedrock, boulders and cobbles which occur in the shallow subtidal zone and typically support rhodophyceae communities as Corallinetum elongatae association (EUNIS A3.11) with bio-concretion on shady vertical rocks at Punta Ferruccio, Ripari di Giobbe and Punta dell'Acquabella and Punta Aderci. The Halymenia floresia association with specimens up to $15 \mathrm{~cm}$ in length is more representative in the Punta Aderci site [18]. In the sheltered and calm waters sites other seaweeds species occurred, such as Ulva sp., Peysonnelia sp., Codium bursa, C. fragile and Dictyota dichotoma.

An important rocky habitat is Sabellaria spinulosa reef (EUNIS A3.6721) more representative along the coast with bioconcretion colonized by Mytilus galloprovincialis facies, with seaweeds, snakelocks anemone Anemonia viridis, bivaleves Ostra edulis and Gastrochaena dubia, gasteropods Trunculariopsis trunculus and Haliotis tubercolata, branching bryozoans Schizoporella errata, echinoderms Arbacia lixula, Sphaerechinus granularis and Paracentrotus lividus and crustaceans Scyllarus arctus, Palaemon elegans and Inachus sp. Moreover, a diversified icthyofauna was sampled: Parablennius gattorugine, P. rouxi, Diplodus vulgaris, D. annularis, Scorphaena porcus, Coris julis and Chromis chromis with an decreasing gradient of species number from North to South and a better status of conservation of Punta Acquabella and Ripari di Giobbe reef (Table 1).

Table 1: Localization of samplings; ID number referred to Fig. 1.

\begin{tabular}{|c|c|c|c|}
\hline ID & Locality & Latitude & Longitude \\
\hline 1 & Ferruccio (Ortona) & $42^{\circ} 22^{\prime} 44.25 » \mathrm{~N}$ & $14^{\circ} 22^{\prime} 46.44 » \mathrm{E}$ \\
\hline 2 & Ripari di Giobbe (Ortona) & $42^{\circ} 22^{\prime} 17.58 » \mathrm{~N}$ & $14^{\circ} 23^{\prime} 45.69 » \mathrm{E}$ \\
\hline 3 & $\begin{array}{c}\text { Spiaggia del Faro } \\
\text { (Ortona) }\end{array}$ & $42^{\circ} 21^{\prime} 38.18 » \mathrm{~N}$ & $14^{\circ} 24^{\prime} 34.49 » \mathrm{E}$ \\
\hline 4 & $\begin{array}{c}\text { Punta dell'Acquabella } \\
\text { (Ortona) }\end{array}$ & $42^{\circ} 20^{\prime} 05.90 » \mathrm{~N}$ & $14^{\circ} 25^{\prime} 38.49 » \mathrm{E}$ \\
\hline 5 & Bardella (Ortona) & $42^{\circ} 19^{\prime} 02.05 » \mathrm{~N}$ & $14^{\circ} 26^{\prime} 16.47 » \mathrm{E}$ \\
\hline 6 & Barriera nord (San Vito) & $42^{\circ} 18^{\prime} 50.97 » \mathrm{~N}$ & $14^{\circ} 26^{\prime} 30.42 » \mathrm{E}$ \\
\hline 7 & Turchino (San Vito) & $42^{\circ} 18^{\prime} 05.10 » \mathrm{~N}$ & $14^{\circ} 27^{\prime} 36.16 » \mathrm{E}$ \\
\hline 8 & $\begin{array}{c}\text { La Foce (Rocca San } \\
\text { Giovanni) }\end{array}$ & $42^{\circ} 16^{\prime} 38.11 » \mathrm{~N}$ & $14^{\circ} 29^{\prime} 42.51 » \mathrm{E}$ \\
\hline 9 & $\begin{array}{c}\text { Scoglione (Torino di } \\
\text { Sangro) }\end{array}$ & $42^{\circ} 12^{\prime} 59.93 » \mathrm{~N}$ & $14^{\circ} 35^{\prime} 02.23 » \mathrm{E}$ \\
\hline 10 & Punta Aderci (Vasto) & $42^{\circ} 10^{\prime} 49.23 » \mathrm{~N}$ & $14^{\circ} 41^{\prime} 16.74 » \mathrm{E}$ \\
\hline 11 & $\begin{array}{c}\text { Grotta del Saraceno } \\
\text { (Vasto) }\end{array}$ & $42^{\circ} 09^{\prime} 15.79 » \mathrm{~N}$ & $14^{\circ} 43^{\prime} 13.37 » \mathrm{E}$ \\
\hline
\end{tabular}

In addition, the presence and the distribution of the cushion coral Cladocora caespitosa, the gorgoniidae Leptogorgia sarmentosa (both Least Concern for IUCN Red List), the date mussel Lithophaga lithophaga (All. IV Hab. Dir.) and the mussel Pholas dactylus (Vulnerable for IUCN Red List) were investigated and the results showed a decrease of their abundance from North to South, except to L. lithophaga with an high presence in the Punta Aderci reef up to 5-6 meters deep and in the Punta Acquabella in co-presence with few individuals of the mussel P. dactylus. The gorgoniidae L. sarmentosa with four colonies $(0,4 \mathrm{spec} . / \mathrm{min})$ only occurred in the Ripari di Giobbe site while cushion coral Cladocora caespitosa is especially present in the northern side of the Teatina coast with a maximum of 33 specimens ( $0.62 \mathrm{spec} . / \mathrm{min}$ ) in the Acquabella reef.

Results showed an high marine biodiversity in species and in number of specimens, especially in the northern side of the study area and a decrease in the southern part; on the contrary to the terrestrial habitats and species are mainly concentrated in the SCIs which are larger in the southern side, as on Torino di Sangro and Vasto $[7,16,17]$.

It worth to note that a dangerous invasive species was found, the veined whelk Rapana venosa, which is homogeneously distributed along whole Teatina coast. 
The CSC along the Teatina coast revealed the presence of the sea turtle Caretta caretta dead or alive and of common small cetaceans as the striped dolphin Stenella coeruleoalba and the bottlenose dolphin Tursiops truncatus, confirming the presence in the central Adriatic Sea of important nursery and

Table 2: List of sea turtles and cetaceans stranded dead or alive from 1999 to 2017 along Teatina coast (Abruzzo, central Italy) (http://geocetus. spaziogis.it/).

\begin{tabular}{|c|c|c|c|c|c|}
\hline Locality & Caretta caretta & Tursiops truncatus & Stenella coeruleoalba & Physeter macrocephalus & Balaenoptera physalus \\
\hline Ortona & 20 & 1 & - & - & - \\
\hline San Vito & 2 & 1 & - & - & - \\
\hline Rocca San Giovanni & - & 2 & - & - & - \\
\hline Fossacesia & 4 & 1 & - & - & - \\
\hline Torino di Sangro & 3 & 2 & - & - & - \\
\hline Casalbordino & 4 & - & 1 & - & - \\
\hline Vasto & 36 & 6 & - & - & 1 \\
\hline San Salvo & 10 & 1 & 1 & - & - \\
\hline TOTAL & 79 & 14 & 8 & \\
\hline
\end{tabular}

\section{Conclusion}

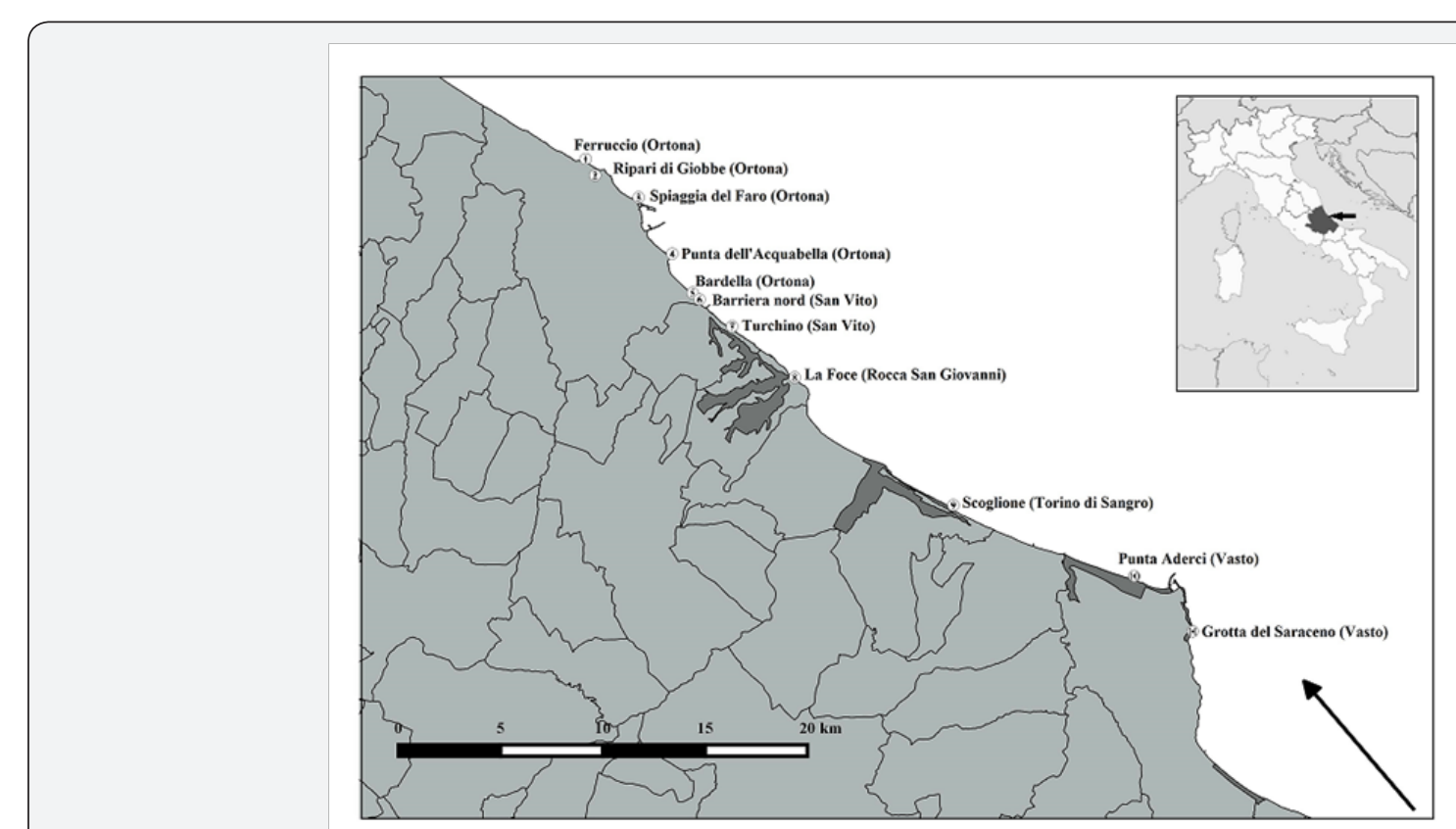

Figure 1: Study area in the Teatina coast. The number referred to the transects listed in the Table 1; in dark grey the terrestrial Sites of Community Importance (Directive 92/43/CEE) along Teatina coast.

The Adriatic Sea represent a very vulnerable ecosystem as it is subjected to continuous pressures by the touristic, fishing, and oil activities compromising the habitats and associated species. Therefore it is necessary to protect, conserve, and manage the coastal and marine areas and their communities [22] with an Integrated Coastal Management ICZM (http://ec.europa.eu/ environment/iczm/) that involves a collaboration between the different stakeholders to manage the environmental and cultural heritage in a sustainable way. Considering the terrestrial Natura 2000 network along Teatina coast (Figure 1) and evaluating our preliminary characterization of marine habitats in the study area we suggest to implement the marine Nature 2000 network

feeding habitats [19], as showed in the Table 2. Furthermore, in the southern Teatina coast were stranded some rare species for a small basin like the Adriatic Sea, that is the sperm whale Physeter macrocephalus and the fin whale Balaenoptera physalus $[20,21]$ (Table 2).

| 
thank the scientific staff of Prof. Carlo Cerrano, Dr. Andrea Rosario Natale (director of Lecceta di Torino di Sangro Natural Reserve, Abruzzo), Dr. Vincenzo Olivieri and his scientific staff of Centro Studi Cetacei and of Recovery Center for sea turtles 'Luigi Cagnolaro' on Pescara (central Italy) for providing useful information. The project was realized in the framework of CONISMA research activities.

\section{References}

1. Coll M, Piroddi C, Albouy C, Ben RLF, Cheung WWL, et al. (2012) The Mediterranean Sea under siege: spatial overlap between marine biodiversity, cumulative threats and marine reserves. Glob Ecol Biogeogr 21(4): 465-480.

2. de Juan S, Lleonart J (2010) A conceptual framework for the protection of vulnerable habitats impacted by fishing activities in the Mediterranean high seas. Ocean Coast Manag 53(11): 717-723.

3. Colantoni P, Mencucci D, Nesci O (2004) Coastal processes and cliff recession between Gabicce and Pesaro (northern Adriatic Sea): a case history. Geomorphology 62(3-4): 257-268.

4. Bastari A, Beccacece J, Ferretti F, Micheli F, Cerrano C (2017) Local Ecological Knowledge Indicates Temporal Trends of Benthic Invertebrates Species of the Adriatic Sea. Front Mar Sci 4: 157.

5. Vatova A (1949) La fauna bentonica dell Alto e Medio Adriatico. Nova Thalassia 1: 3-110.

6. Scaccini A (1967) Dati preliminari sulle zoocenosi bentoniche e sulla biomassa in una zona dell Alto e Medio Adriatico. Note del Laboratorio di Biologia Marina Pesca Fano II (Italy) 3: 25-56.

7. de Francesco MC, Zuzolo A, Carranza ML, Frate L, Natale AR, et al (2016) Copertura del suolo e biodiversità nella costa Teatina (Abruzzo, Italy). Sixth International Symposium Monitoring of Mediterranean coastal areas: problems and measurement techniques, Livorno, Italy, 27-36.

8. Guidetti P (2000) Differences Among Fish Assemblages Associated with Nearshore Posidonia oceanica Seagrass Beds, Rocky-algal Reefs and Unvegetated Sand Habitats in the Adriatic Sea. Estuar Coast Shelf Sci 50(4): 515-529.

9. Bianchi CN, Pronzato R, Cattaneo-VR, Benedetti CL, Morri C, et al (2003) I fondi duri. In: Gambi MC, Dappiano M (Eds.), Manuale di Metodologie di campionamento e studio del benthos marino mediterraneo. (Edition), Biol Mar Med 10 (Suppl): 199-232.
10. D Onofrio D (2017) Caratterizzazione bionomica delle comunità bentoniche costiere di fondo duro del tratto di costa compreso tra Ortona e Vasto. Thesis in Marine Biology of Polytechnical University of Marche, Italy, pp. 96.

11. AA VV (2007) Guidelines for the establishment of the Natura 2000 network in the marine environment. Application of the Habitats and Birds Directives.

12. Devilliers P, Devilliers-TJ (1998) A classification of Palaearctic habitats. Nature and Environ 78: 194.

13. APAT (2004) Gli habitat secondo la nomenclatura Eunis: manuale di classificazione per la realtà italiana. (edn), APAT Rapporti, 39/2004, Rome, Italy, pp. 160.

14. Cagnolaro L (1985) Il I Convegno Nazionale sui Cetacei ed il Centro Studi Cetacei della Società Italiana di Scienze Naturali. Natura 76(1-4): 118-120.

15. Cagnolaro L (1992) Il Centro Studi Cetacei della Società Italiana di Scienze Naturali: Origine, finalità ed organizzazione. Marine Ecosystem in Italy and along Latial coast, International Symposium of Marine Ecosystem Studies, Rome, Italy: 81-86.

16. Stanisci A, Acosta ATR, Carranza ML, de Chiro M, Del Vecchio S, et al. (2014) EU habitats monitoring along the coastal dunes of the LTER sites of Abruzzo and Molise (Italy). Plant Sociol 51(1): 51-56.

17. Prisco I, Stanisci A, Acosta ATR (2016) Mediterranean dunes on the go: Evidence from a short term study on coastal herbaceous vegetation. Estuar Coast Shelf Sci 182: 40-46.

18. Giaccone G, Alongi G, Pizzuto F, Cossu A (1994) La vegetazione marina bentonica fotofila del Mediterraneo: II. Infralitorale e Circalitorale. Proposte di aggiornamento. Boll Acc Gioenia Sci Nat Catania 27(346): 111-157.

19. Lazar B, Margaritoulis D, Tvrtkovic N (2004) Tag recoveries of the loggerhead sea turtle Caretta caretta in the eastern Adriatic Sea: implications for conservation. Mar Biol Ass U.K. 84: 475-480.

20. Bolognari A (1957) Sulla biologia del capodoglio. Atti Soc Pelor Sci Fis Mat Nat 3 (2): 143-156.

21. Cagnolaro L, Di Natale A, Notarbartolo di Sciara G (1983) Guida per il riconoscimento delle specie animali delle acque lagunari e costiere italiane. Cetacei. (Edition) CNR AQ/1/224, Rome, Italy, pp. 183.

22. Balsamo M, Penna A, Semprucci F, Coccioni R, Frontalini F, et al. (2011) The coast of the S. Bartolo SCI (Marches, Italy) as a site in a network of Adriatic areas of conservation interest. Varstvo Narave Supl.1: 173174 .

\section{Your next submission with Juniper Publishers will reach you the below assets}

- Quality Editorial service

- Swift Peer Review

- Reprints availability

- E-prints Service

- Manuscript Podcast for convenient understanding

- Global attainment for your research

- Manuscript accessibility in different formats

( Pdf, E-pub, Full Text, Audio)

- Unceasing customer service

Track the below URL for one-step submission

https://juniperpublishers.com/online-submission.php 